\title{
ASSESSING THE VOLUME FRACTIONS OF THE PHASES, NODULARITY AND NODULE COUNT OF SPHEROIDAL GRAPHITE CAST IRON USING IMAGEJ SOFTWARE
}

\author{
Selin TORAMAN \\ Department of Metallurgical and Materials Engineering, Hitit University, Turkey, selintoraman@gmail.com \\ (D) https://orcid.org/0000-0001-8775-7791 \\ Tugay COSGUN \\ Department of Metallurgical and Materials Engineering, Hitit University, Turkey, tugaycosgun17@gmail.com \\ (iD) https://orcid.org/0000-0003-4538-8697 \\ Bulent ALKAN \\ Department of Metallurgical and Materials Engineering, Hitit University, Turkey, bulentalkan@hitit.edu.tr \\ (iD) https://orcid.org/0000-0003-1048-7986 \\ Baris CETIN \\ Engineering and Research Department, FNSS Defense Systems Co. Inc., Turkey, cetin.baris@fnss.com.tr \\ (iD) https://orcid.org/0000-0001-8615-8383 \\ Oncu AKYILDIZ* \\ Department of Metallurgical and Materials Engineering, Hitit University, Turkey, oncuakyildiz@hitit.edu.tr \\ (iD) https://orcid.org/0000-0002-0081-1642 \\ Research Article \\ DOI: $10.22531 /$ muglajsci.521128
}

Received: 01.02.2019, Accepted: 12.06.2019

*Corresponding author

\begin{abstract}
In this study, a simple method for assessing the microstructure of ductile cast iron by using a freeware digital image processing software is described. The method is applied to three different ductile iron grades to assess their ferrite, pearlite and graphite volume fractions as well as graphite nodularity, nodule count, nodule size. All specimens were found to show good nodularity ( $~ 88 \%$ by area) with different graphite average size and perimeter morphology. The amount of graphite was also found to be similar (11 $\pm 2 \%$ by area) in all specimens. On the other hand, ferrite percentages were found as 85.8 , 57.1, and $52.5 \%$ respectively for ASTM A536 grades 60-40-18, 65-45-12, and 80-55-06. It was also found that among these three grades, the higher the pearlite content, the higher the hardness. The agreement with the standards confirms that quantitative metallography through image processing is a powerful tool in order to estimate the mechanical properties of cast irons.
\end{abstract}

Keywords: Spheroidal Graphite Cast Iron, Image Processing, ImageJ

\section{KÜRESEL GRAFITTLİ DÖKME DEMİRLERDE FAZLARIN HACIM ORANI, NODÜLARİTE VE NODÜL SAYISININ IMAGEJ YAZILIM PROGRAMI KULLANILARAK DEĞERLENDİRÍLMESİ}

\section{Özet}

Bu çalışmada, küresel grafitli dökme demirlerin mikro yapılarını nicel olarak tanımlamak için ücretsiz dijital görüntü işleme yazılımının kullanıldığı basit bir yöntem açıklanmıştır. Yöntem üç farklı küresel grafitli dökme demir türüne uygulanarak, bunların içyapılarındaki ferrit, perlit ve grafit faz oranları, grafit nodülerliği, nodül sayısı, nodül büyüklüğünü değerlendirilmiștir. Örneklerin iyi derecede nodülerlik (alana göre \% 88) gösterdiği, farkl grafit ortalama büyüklügüne ve çevre morfolojisine sahip oldukları bulunmuştur. Tüm örneklerde grafit miktarının da benzer olduğu (alana göre \% 11 \pm 2 ) bulunmuştur. Öte yandan, ASTM A536 sinıfları 60-40-18, 65-45-12 ve 80-55-06 için ferrit yüzdeleri sirasıyla \% 85.8, 57.1 ve\% 52.5 olarak hesaplanmıştır. Ayrıca, bu üç sınıf arasında, perlit içeriği arttıkça sertliğin arttığı gösterilmiştir. Sonuçların standartlar ile uyumlu olmasl, görüntü işleme yoluyla kantitatif metalografinin dökme demirlerin mekanik özelliklerini tahmin etmek için güçlü bir araç olduğunu göstermiştir.

Anahtar Kelimeler: Küresel Grafitli Dökme Demir, Görüntü İşleme, ImageJ

Cite

Toraman, S., Coşgun, T., Alkan, B., Çetin, B., Akyıldız, Ö. (2019). “Assessing the volume fractions of the phases, nodularity and nodule count of spheroidal graphite cast iron using ImageJ software”, Mugla Journal of Science and Technology, 5(1), 137142. 


\section{Introduction}

Ductile iron refers to a particular class of cast iron with spheroidal (or nodular) graphites in a ferritic/pearlitic matrix phase. This particular graphite shape, which is achieved by inoculating small amounts of magnesium and/or cerium, delivers the material standard advantages of gray cast iron (low melting point, good fluidity and castability, excellent machinability, and good wear resistance) with the engineering advantages of steel (high strength, toughness, ductility, hot workability and hardenability) [1]. Different grades of ductile iron can be produced by controlling the constituents of the matrix phases through the addition of other alloying elements [2,3] and heat treatments [4]. The high ductility grades require a maximum of ferrite and a minimum of pearlite, whereas high strength grades require considerable pearlite [5]. In other words, the ductile iron could meet the desired mechanical properties only if the ferrite/pearlite ratio, the nodularity and the quantity of the graphite particles are proper and adequate. Therefore, quantitative analysis of the microstructure of ductile iron is of practical importance.

Image acquisition, digital processing, segmentation (threshold operations), mathematical morphological operations and measurements comprise the essential steps of quantitative analysis through image processing of digital micrographs. The easiest method for image segmentation (locating image boundaries to isolate objects) is thresholding. The output of thresholding is a binary image with black pixels (i.e. pixel value $=0$ ) belonging to a target feature in the white background (pixel value $=1$ ) [6].

Examples of digital image processing techniques applied to cast irons using several different software are available in the literature [7-12]. Furthermore, many metallography laboratory equipment vendors like Olympus [13] and Nikon Instruments [14, 15] provide software modules for quantitative analysis of cast irons. Image $[16,17]$ on the other hand, provides a free alternative for digital image processing.

The current work aims to describe a similar method performed on three different ductile iron grades using Image $[16,17]$. The nodularity of the graphites was evaluated in accordance with the ASTM E2567 standard [18] and their ferrite, pearlite and graphite volume fractions were determined. The related literature generally deal with the computation of nodularity only, and to best of our knowledge there exists no manuscript that computes both nodularity and phase fractions of the specified castings in comparison.

\section{Material and Method}

The cast iron grades used in this contribution were ASTM A536 grades 60-40-18, 65-45-12, and 80-55-06 (the grade sequentially indicates the tensile strength (Ksi), yield strength (Ksi), and percent elongation at failure) with a fully ferritic and ferritic/pearlitic matrices.

Preparation of metallographic specimens and evaluation of microstructures were performed according to ASTM standards [18, 19]. Ductile cast iron samples were encapsulated in a round bakelite (Metkon-Phenolic resin powder) mount with a diameter of $40 \mathrm{~mm}$. The specimens were mechanically ground with 180 to 1200 grit $\mathrm{SiC}$ paper then polished with $1 \mu \mathrm{m}$ monocrystalline diamond suspension to mirror finish (Metkon Forcipol $1 \mathrm{~V}$ Grinder-Polisher). Finally, the samples were etched with Nital reagent (2-4 mL nitric acid (HNO3) and 96-98 $\mathrm{mL}$ ethanol). After the metallographic treatments, specimens were cleaned in an ultrasonic bath using ethanol for $10 \mathrm{~min}$. and then dried. Micrographs of the specimens before and after etching were captured by using Nikon ECLIPSE LV150N. Microhardness measurements were taken by using Metkon DUROLINEM. SEM analyses were performed by FEI / Quanta 450 FEG scanning electron microscope.

The flowchart for computing the nodularity, nodule count and volume fractions of the phases using the image processing is given in Figure 1. For nodularity calculations, micrographs of polished surfaces were opened in Image and converted to an 8-bit color by clicking Image/Type/8-bit tab. The micrographs were then scaled by drawing a straight line along the length of the scale bar using the line tool and entering the bar length as known distance in Analyze/Set Scale tab. Graphitic particles were distinguished using Image/Adjust/Threshold tab and using the eraser tool graphite particles that stuck together were deleted. Under Analyze/Set Measurements tab area, area fraction and Feret's diameter options were selected and using Analyze/Analyze Particles tab measurements were taken. The micrographs of the same surfaces after etching were used to distinguish dark regions composed of graphite and pearlite from the white ferrite background. This information was used to determine the volume fractions of the phases. 

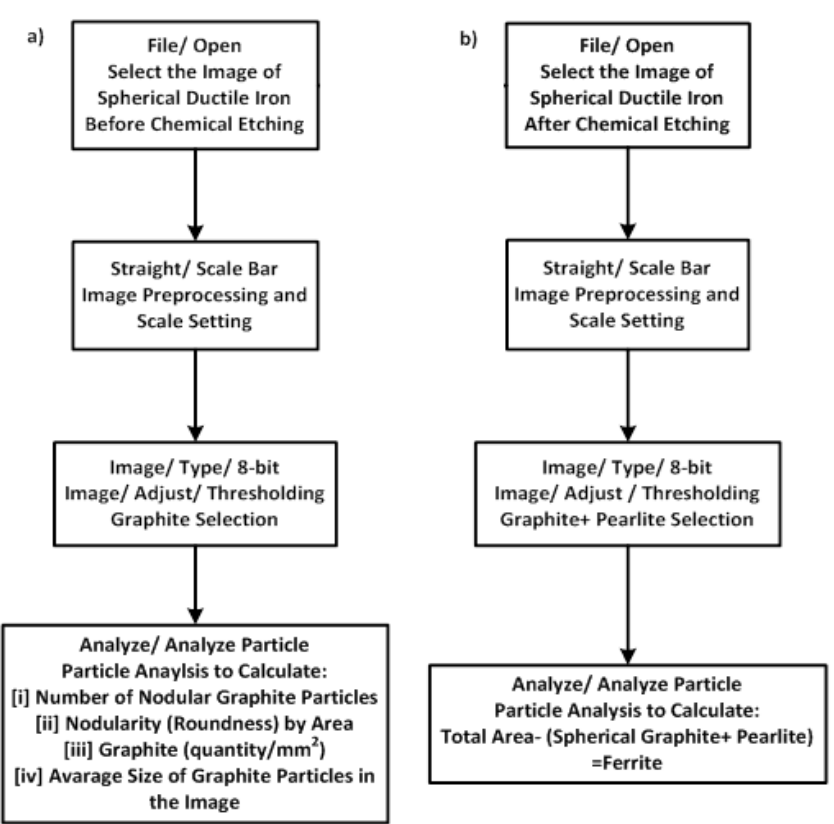

Figure 1. Flowcharts for computing a) nodularity ratings and b) volume fractions of the phases.

\section{Results and Discussion}

Micrographs of the specimens before and after etching are presented in Figure 2. These digital images are converted to 8-bit and segmented through thresholding as shown in Figure 3. From the as polished condition, the shape of graphite particles was evaluated using the area of "reference circle" which is calculated by the "maximum ferret diameter (MFD)". This parameter can be defined as the maximum distance between pairs of parallel tangents to the projected outline of the particle. The shape factor (SF) of graphite particles was then defined as the ratio of the area of graphite particles over the area of the reference circle [18]. For a perfect circle, the $\mathrm{SF}$ is 1 , and it approaches zero when the particle shape becomes less round. A particle is considered as graphite if its MFD is at least $10 \mu \mathrm{m}$ (size criteria). A graphite particle is qualified as "spheroidal graphite (nodular graphite) when its SF is at least 0.6 (SF criteria). Overall SF distributions of three different grades are given in Figure 4.

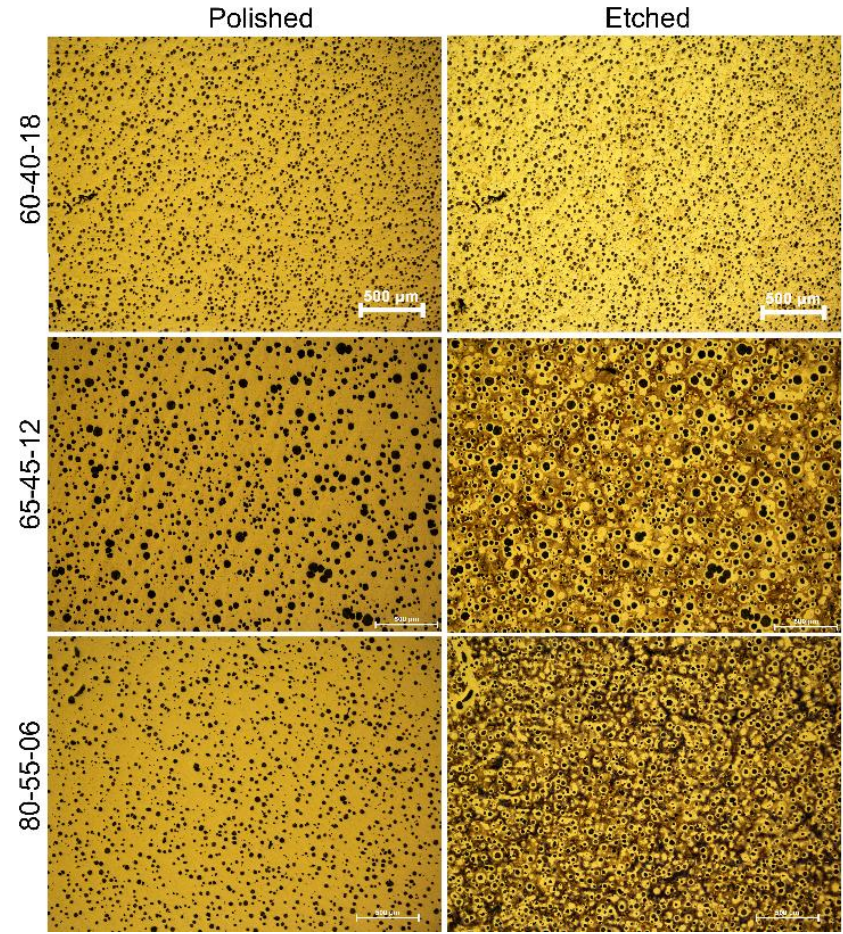

Figure 2. Optical micrographs of the samples in aspolished and etched conditions taken at $50 \mathrm{x}$ magnification.

For all specimens, the highest fraction of graphite particles have an SF of $\sim 0.8$. The $65-45-12$ specimen has more fraction of graphite particles with SF less than 0.6 (non-nodular particles).

The area and number fractions of the particles that satisfy the size and SF criterion is calculated and given in Figure $5 \mathrm{a}$. This figure shows that all the specimens have similar nodularity by area value of $\sim 88 \%$. Although the 65-45-12 sample has the highest total nodular graphite area, the number of nodular graphite particles is smaller than that of other specimens, which suggests that the 6545-12 sample contains bigger graphite particles. This is best illustrated in Figure $5 \mathrm{~b}$ and supported by the SEM micrographs given in Figure 6.

The SEM micrographs given show that the perimeter morphology of graphites is different in each sample. Especially, 65-45-12 sample composed of imperfect graphite spherulites with separated sectors. Advanced segmentation methods like active contour method [20] and shape factors that are sensitive to surface irregularities [21] can be utilized in order to quantify the effect of perimeter morphology. 


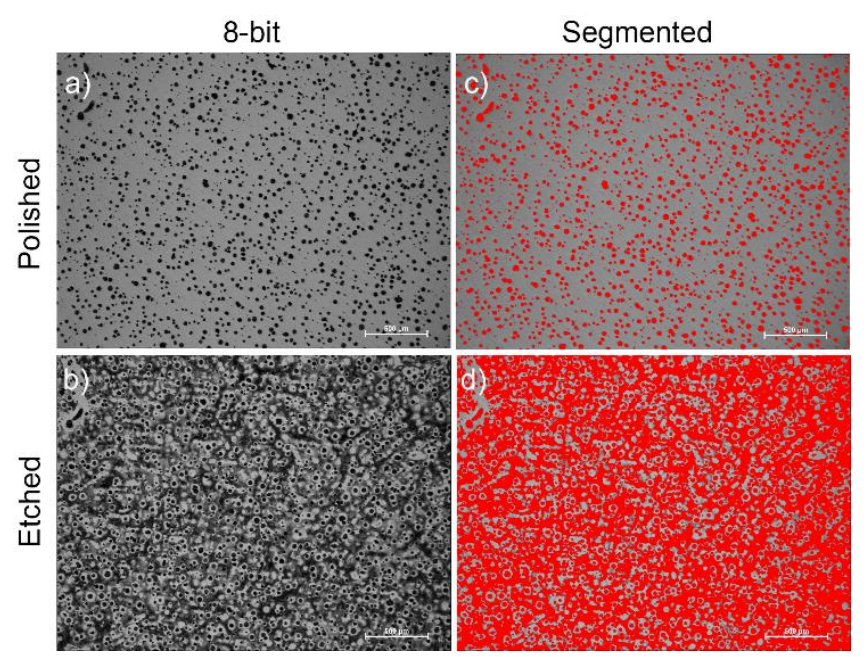

Figure 3. Optical micrographs of 80-55-06 sample converted to 8-bits and segmented in a, c) as polished and $b, d$ ) etched conditions.

Figure $7 \mathrm{a}$ compares graphite, pearlite and ferrite percentages in all samples. $60-40-18$ has a ferritic structure with $85.83 \%$ ferrite where the other two specimens have ferritic + pearlitic structures. These fractions are calculated using the micrographs before and after etching as described in the methods section. First, the area of graphite, and then the area of graphite

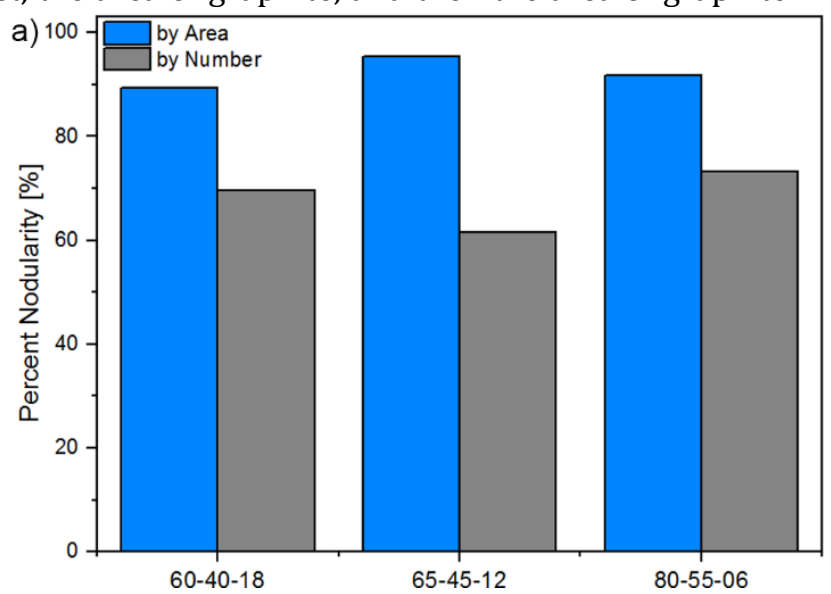

plus pearlite phases are determined together. Subtracting the latter from the total area, the area of ferrite and subtracting the area of graphite particles from the latter, the area of pearlite is determined. 80-55-06 specimen has the highest pearlite content (38.4\%).

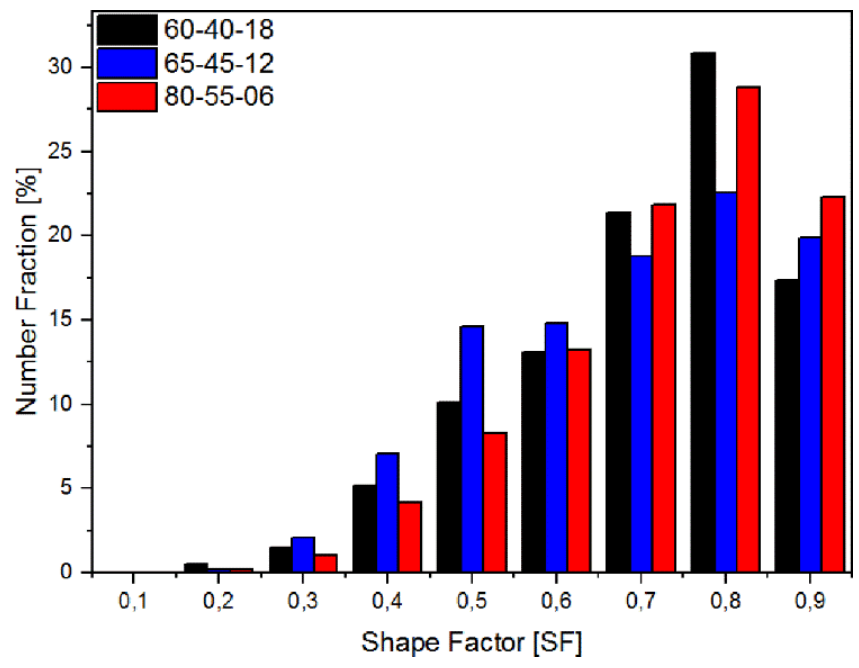

Figure 4. The shape factor distributions of the graphite particles in each sample.

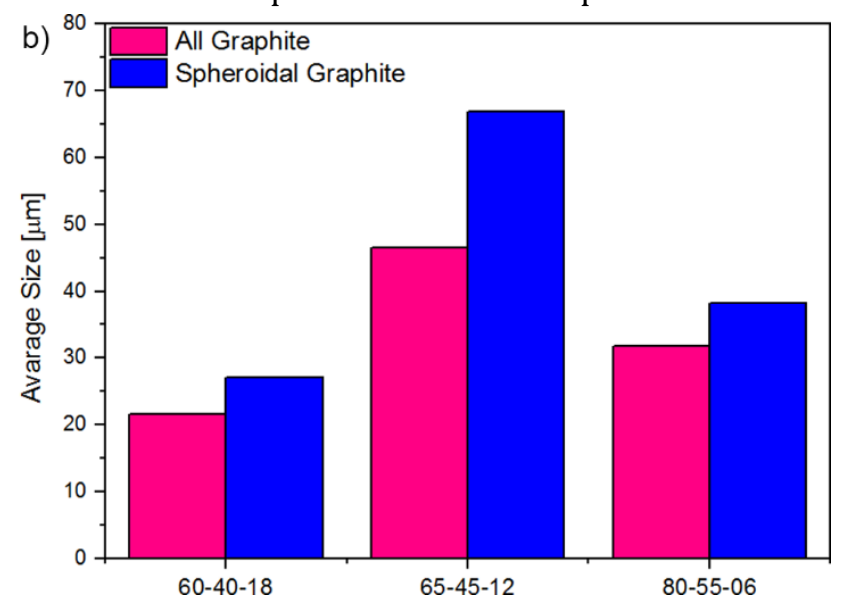

Figure 5. a) calculated percent nodularity values by area and by number, b) calculated average particle sizes.

In order to assess the effect of volume fractions of the phases to mechanical properties, Vickers hardness was measured on the surfaces of the specimens with $4.913 \mathrm{~N}$ load. Six points near graphite, ferrite, and pearlite were sampled. According to the results given in Table 1, the hardness of the specimens are 138.46, 184.21 and 220.20 HV respectively for ASTM A536 grades 60-40-18, 65-4512 , and 80-55-06. 
a)

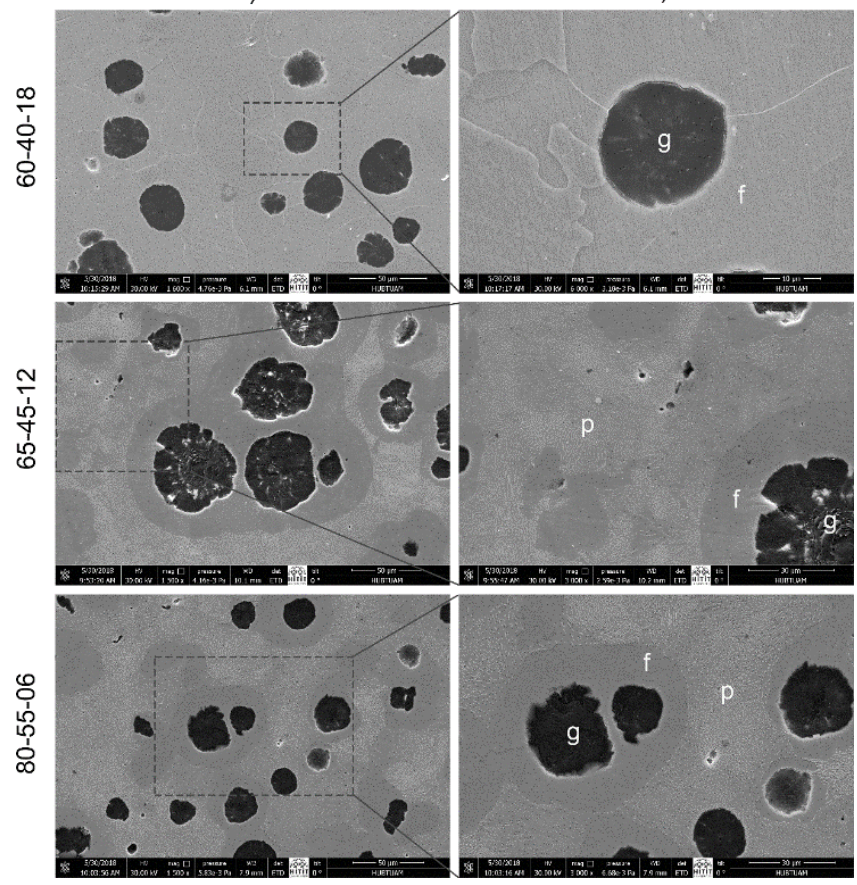

Figure 6. Scanning electron micrographs of the etched specimens taken at a) 1500x and b) higher magnifications. In the SEM micrographs, the microstructural features are indicated as graphite (g), ferrite (f) and pearlite (p).

In Figure 7 the hardness values are plotted in connection with volume fractions of the phases. It is observed that the sample with the highest pearlite content (80-55-06)

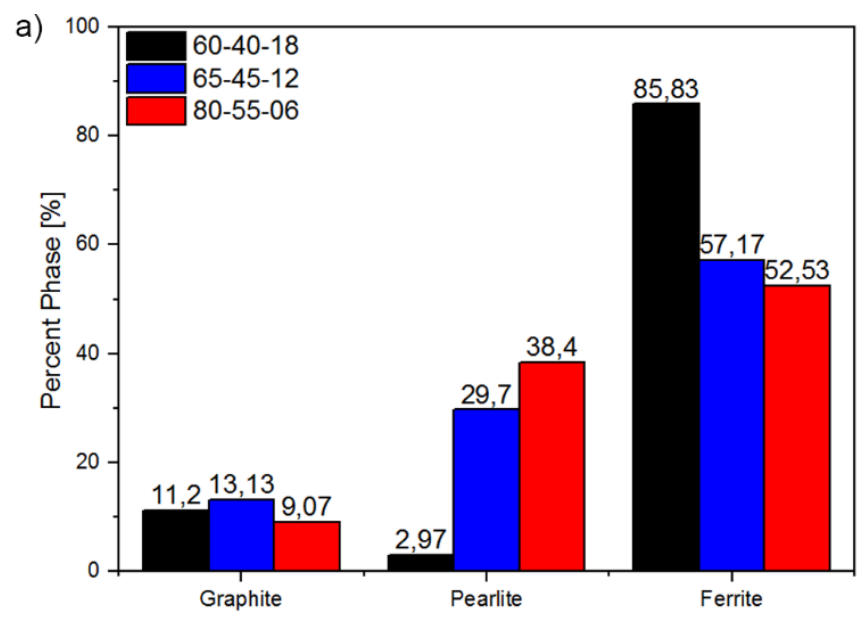

has the highest hardness value of $220.20 \mathrm{HV}$. All measured hardness values are within the intervals as prescribed by the ASTM standard and a summary of measured and calculated data is given in Table 2 .

Table 1. Measured hardness values for each sample. The diagonals $\mathrm{d} 1, \mathrm{~d} 2$ are in $\mu \mathrm{m}$ and six points near graphite, ferrite, and pearlite were sampled.

\begin{tabular}{|c|c|c|c|c|c|c|c|c|c|}
\cline { 2 - 10 } \multicolumn{1}{c|}{} & \multicolumn{3}{|c|}{$\mathbf{6 0 - 4 0 - 1 8}$} & \multicolumn{3}{c|}{$\mathbf{6 5 - 4 5 - 1 2}$} & \multicolumn{3}{|c|}{$\mathbf{8 0 - 5 5 - 0 6}$} \\
\hline Test No & $\mathbf{d}_{\mathbf{1}}$ & $\mathbf{d}_{\mathbf{2}}$ & $\mathbf{H V}$ & $\mathbf{d}_{\mathbf{1}}$ & $\mathbf{d}_{\mathbf{2}}$ & $\mathbf{H V}$ & $\mathbf{d}_{\mathbf{1}}$ & $\mathbf{d}_{\mathbf{2}}$ & $\mathbf{H V}$ \\
\hline $\mathbf{1}$ & 83.69 & 85.36 & 129.74 & 60.1 & 63.55 & 242.30 & 64.5 & 65.86 & 218.05 \\
\hline $\mathbf{2}$ & 78.54 & 78.72 & 149.95 & 67.8 & 67.03 & 203.71 & 67.9 & 72.34 & 188.41 \\
\hline $\mathbf{3}$ & 90.98 & 86.86 & 117.24 & 63.5 & 62.33 & 234.19 & 60.5 & 56.48 & 270.90 \\
\hline $\mathbf{4}$ & 77.40 & 79.54 & 150.55 & 92.7 & 88.78 & 112.50 & 68.5 & 69.31 & 195.21 \\
\hline $\mathbf{5}$ & 78.75 & 79.74 & 147.62 & 73.5 & 81.30 & 154.60 & 62.4 & 63.28 & 234.43 \\
\hline $\mathbf{6}$ & 82.91 & 82.41 & 135.68 & 77.0 & 76.20 & 157.94 & 65.3 & 66.26 & 214.16 \\
\hline & \multicolumn{2}{|c|}{ Mean } & 138.46 & Mean & 184.21 & Mean & 220.20 \\
\hline
\end{tabular}

Table 2. Calculated nodularity, graphite quantity per $\mathrm{mm}^{2}$, volume fractions of the phases of graphite, pearlite, ferrite and measured and expected hardness values for each sample.

\begin{tabular}{|lc|c|c|}
\cline { 2 - 4 } \multicolumn{1}{c|}{} & $\mathbf{6 0 - 4 0 - 1 8}$ & $\mathbf{6 5 - 4 5 - 1 2}$ & $\mathbf{8 0 - 5 5 - 0 6}$ \\
\hline Nodularity (\%) & 87.61 & 88.21 & 88.19 \\
\hline Graphite (quantity/mm²) & 362.41 & 173.53 & 209.11 \\
\hline Graphite (\%) & 11.20 & 13.13 & 9.07 \\
\hline Perlite (\%) & 2.97 & 29.70 & 38.40 \\
\hline Ferrite (\%) & 85.83 & 57.17 & 52.53 \\
\hline Hardness (measured, HV) & $138.46 \pm 5.47$ & $184.21 \pm 20.79$ & $220.20 \pm 12.18$ \\
\hline Hardness (ASTM A536, HV) & $124-140$ & $175-225$ & $220-255$ \\
\hline
\end{tabular}

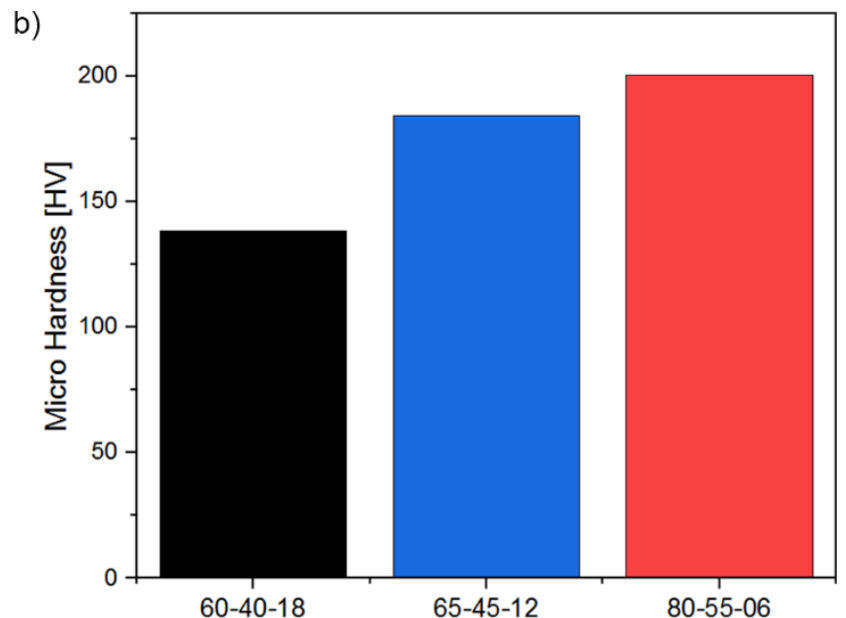

Figure 7. a) calculated graphite, pearlite and ferrite percentages, and b) measured hardness values in Vickers scale (HV).

\section{Conclusion}

In this study, a method for quantitatively describing the microstructure of ductile cast irons, which may easily be adapted to foundry quality control practice to inhibit low nodularity ratings and to ensure proper volume fractions of the phases for high strength or high ductility without any cost, is described. All specimens were found to show good nodularity ( $~ 88 \%$ by area) with similar amounts $(11 \pm 2 \%$ by area). On the other hand, ferrite percentages were found as 85.8, 57.1, and $52.5 \%$ respectively for ASTM A536 grades 60-40-18, 65-45-12, and 80-55-06. Among these 80-55-06 found to show a higher hardness value of $220.2 \mathrm{HV}$ due to its higher pearlite content. The present work confirms that quantitative metallography 
through image processing is a powerful tool in order to estimate the mechanical properties of cast irons.

\section{Acknowledgments}

The authors wish to thank K. Davut of Atılım University and H. Meço of FNSS Defense Systems Co. Inc. for their constant interest and valuable advice in this project.

\section{References}

[1] Oluwole 00, Olorunniwo OE, Ogundare 00, Atanda PO and Oridota 00, "Effect of Magnesium and Calcium as Spheroidizers on the Graphite Morphology in Ductile Cast Iron", Journal of Minerals \& Materials Characterization \& Engineering 6, 1, 25$37,2007$.

[2] Omole SO, Oyetunji A, Alaneme KK, Olubambi PA, "Structural characterization and mechanical properties of pearlite - Enhanced micro-alloyed ductile irons", Journal of King Saud University Engineering Sciences, In Press, Corrected Proof, 2018.

[3] González-Martínez R, De La Torre U, Ebel A, Lacaze J, and Sertucha J, "Effects of high silicon contents on graphite morphology and room temperature mechanical properties of as-cast ferritic ductile cast irons. Part II-Mechanical properties", Materials Science and Engineering: A, 712, 803-811, 2018.

[4] Yürektürk Y, and Baydogan M, "Estimating Volume Fractions of Microstructural Constituents in Austempered High Silicon Alloyed GJS 600-10 Ductile Iron through Magnetic Measurements (VSM)“, Materials Science Forum. 907, 50-55, 2017.

[5] Ductile Iron Quality Assurance Guide by Ductile Iron Society; https://www.ductile.org/

[6] Szczotok A, "Guidance and advice to image analysis applied in materials science", Technical Transactions, Mechanics Issue 3-M, 10, 15-21, 2016.

[7] Imasogie BI, Wendt U., "Characterization of Graphite Particle Shape in Spheroidal Graphite Iron using a Computer-Based Image Analyser", Journal of Minerals and Materials Characterization and Engineering 3, 1 1-12, 2004.

[8] Albuquerque V, Tavares JMRS, Cortez P., "Quantification of the Microstructures of Hypoeutectic White Cast Iron using Mathematical Morphology and an Artificial Neuronal Network", International Journal of Microstructure and Materials Properties 5, 1, 52-64, 2010.

[9] Sarojadevi H, Shetty AB, Murthy AK, Shetty PB, Mukunda PG, "Digital Image Processing Technique for Microstructure Analysis of Spheroidal Graphite Iron“, International Journal of Combined Research \& Development 1, 4, 2321-2241, 2013.
[10] Godbole S, Jayashree V, "Microstructure analysis of spheroidal graphite iron (SGI) using hybrid image processing approach", International Journal of Advanced Research in Computer Engineering \& Technology 3, 7, 2268-2273, 2014.

[11] Mirashi A, Jayashree V, "Microstructure analysis of cast iron using image processing", International journal of innovations in egineering technology 6,2 409- 417, 2015.

[12] Davut K, Çetin B, Arslan E, Meço H, Yazganarıkan C, "Nodularity and Nodule Count Analysis of Austempered Ductile Iron Castings by Digital Image Processing", 18th International Metallurgy \& Materials Congress 497-500, 2016.

[13] Olympus Industrial Resources, Application Notes, Cast Iron Analysis, https://www.olympusims.com/en/applications/cast-iron-analysis/, accessed: 05/07/2019.

[14] NIS Elements, Industrial, Metallography, Cast Iron Analysis Module, http://www.nis-elements.cz/en/ solutions/industrial/26, accessed: 05/07/2019.

[15] CLEMEX, Image Analysis Report 331, Porosity Analysis, http://www.clemex.com/clemex/media/ assets/pdf/Applications/Image-Analysis-Reports/ 331 CastIron Porosity.pdf?ext=.pdf, accessed: 05/ $07 / 2019$.

[16] Schneider CA, Rasband, WS, Eliceiri KW, "NIH Image to ImageJ: 25 years of image analysis", Nature Methods 9, 7, 671-675, 2012.

[17] Rueden CT, Schindelin J, Hiner MC. et al., "ImageJ2: ImageJ for the next generation of scientific image data“, BMC Bioinformatics 18, 529, 2012.

[18] ASTM E2567-14, Standard Test Method for Determining Nodularity and Nodule Count in ductile Uron Using Image Analysis. ASTM International, West Conshohocken, PA, 2014, www.astm.org

[19] ASTM A247 - 17, Standard Test Method for Evaluating the Microstructure of Graphite in Iron Castings. ASTM International, West Conshohocken, PA, 2014, www.astm.org

[20] Santis A. De, Bartolomeo O. Di, Iacoviello D., Iacoviello F., "Quantitative shape evaluation of graphite particles in ductile iron", Journal of Materials Processing Technology 196, 292-302, 2008.

[21] Vasko A., "Evaluation of shape of graphite particles in cast irons by a shape factor", Materials Today: Proceedings 3, 1199-1204, 2016. 